\title{
HARTIAN POSITIVISM AS A (PLAUSIBLE) ERROR THEORY
}

\author{
Fábio Perin SHECAIRA*
}

Resumen:

Los críticos del positivismo jurídico hartiano han caracterizado este enfoque como una teoria del error sobre el discurso judicial - concretamente sobre la argumentación judicial en el contexto de desacuerdos relacionados con una metodología de interpretación apropiada-. Los críticos también han sugerido que el positivismo hartiano, al igual que otras teorias del error en otros campos de la filosofia, ha de ser tomada por falsa. El propósito de este artículo es ofrecer una explicación más cuidadosa de la naturaleza y alcance del error que los positivistas hartianos atribuyen a los jueces. Se argumentará que el positivismo hartiano, aun cuando pudiera ser entendida como una forma de teoría del error, no debería ser relacionada con, por ejemplo, teorias del error en metaética, donde el error relevante es omnicomprensivo y misteriosamente permanente.

\section{Palabras clave:}

Positivismo jurídico, teoría del error, desacuerdo de interpretación, metaética, H. L. A. Hart.

* Helpful comments on an earlier, longer version of this paper were provided by Matt Grellette, Nick Griffin, Karl Laderoute, Stefan Sciaraffa, Noel Struchiner, Wil Waluchow and participants in the PhD philosophy seminar at McMaster University. I am indebted to Heather Kuiper for comments on the current version. 


\section{FÁBIO PERIN SHECAIRA}

\section{Abstract:}

Critics of Hartian legal positivism have characterized it as an error theory about judicial discourse -more precisely, about judicial argument in contexts of disagreement about proper interpretive methodology-. The critics have also suggested that Hartian positivism, like error theories in other areas of philosophy, is to be presumed false. The purpose of this paper is to give a precise account of the nature and extent of the error assigned to judges by Hartian positivists. It will be argued that Hartian positivism, even if it can be understood as a form of error theory, should not be likened to, say, error theories in metaethics, where the relevant error is pervasive and mysteriously enduring.

Keywords:

Legal Positivism, Error Theory, Interpretive Disagreement, Metaethics, H. L. A. Hart. 
Summary: I. Introduction. II. Problems with (P2). III. Why Believe that Judicial Interpretation is Rule-Governed? IV. Conclusion.

\section{INTRODUCTION}

A number of legal philosophers (henceforth "the critics") recently offered an objection to Hartian positivism (henceforth "HP") that deserves careful consideration. ${ }^{1}$ What follows is a reconstruction of the argument grounding the critics' objection:

(P1) Error theories are to be presumed false;

(P2) HP is an error theory;

(C) Therefore, HP is to be presumed false.

(P1) asserts what appears to be a well-established view in other areas of philosophy, if not yet in jurisprudence: a theory about an entrenched type of discourse or mode argument that characterizes it as systematically flawed (e.g. as resting on a false set of assumptions) is to be presumed false. The presumption, of course, can be defeated; but the burden of argument is assigned to the proponents of the error theory. I will not question the truth of (P1) in this paper; (P2) will be the main target of my criticisms.

Why would HP be regarded as an error theory? An answer to this question requires a bit of background. HP is often associated with the claim that the content of the law depends on official consensus. This claim is ambiguous because the phrase "content of the law" is ambiguous. H. L. A. Hart clearly believed that the rule of recognition has its content fixed by official consensus. And the rule of recogni-

1 These are some of the critics I have in mind: M. Berman, "Constitutional Theory and the Rule of Recognition: Toward a Fourth Theory of Law," in M. Adler and K. Himma (ed.), The Rule of Recognition and the U.S. Constitution (New York: Oxford University Press, 2009); S. Sciaraffa, "The Justificatory View and Theoretical Disagreement" (forthcoming in Problema. Anuario de Filosofia y Teoria del Derecho); and S. Shapiro, "What Is the Rule of Recognition (And Does It Exist)?", in M. Adler and K. Himma (ed.), The Rule of Recognition and the U.S. Constitution (New York: Oxford University Press, 2009). 
tion has the undisputed function of specifying criteria that are used to determine which norms are valid (i.e. binding) within a legal system. ${ }^{2}$ It is a different and more controversial question whether Hart thought that the rule of recognition also serves the function of specifying proper methods for interpreting norms which it recognizes as valid. So, there are two ways of understanding the claim attributed to HP, namely, that the content of the law is determined by official consensus. On one interpretation, official consensus determines the norms which are binding within a given legal system. On the other interpretation, official consensus determines not only what norms are binding within a legal system but also the proper methods for interpreting binding norms.

I am not sure which of the two interpretations of Hart's theory is correct. I will assume, for the sake of argument, that the second interpretation is correct, since it is on that interpretation that the critics seem to rely. This brings us back to the question, why would HP be deemed and error theory? If HP claims that the content of the law is fixed by official consensus, then it follows that whenever officials disagree either about criteria of validity or about proper interpretive methodology, the content of the law is indeterminate. But, the critics argue, judicial disagreement about proper interpretive methodology is a common occurrence in legal systems like that of the US. Judges disagree about how to determine the meaning of valid legal norms (some judges are textualists, some are intentionalists, others are purposivists, etc.), and - here comes the important partthey do so while arguing as if they were advancing claims about what the law "is" or "requires." Recall that, for HP, if judges disagree about proper interpretive methodology, then the law is indeterminate, i.e. it does not yet require any specific course of action (unless, of course, different methods yield identical interpretations; but there is no

2 H. L. A Hart, The Concept of Law (Oxford: Clarendon Press, 1961), Chapters 5 and 6 . 
guarantee that that should happen). So, defendants of HP have no option but to characterize judicial discourse in circumstances of disagreement about proper interpretive methodology as flawed: judges talk as if they were discerning what the law requires when, as a matter of fact, the law makes no determinate requirements. HP is an error theory insofar as it attributes to judges a mistaken belief (or perhaps a knowingly false belief, in which case judges would not be misguided but insincere) that underlies judicial argument in circumstances of disagreement about proper interpretive methodology.

I have two central aims in this paper. The first one is to show that (P2) is unjustified. HP may indeed be characterized (loosely speaking) as an error theory, but the error it identifies is neither widespread enough nor mysterious enough to warrant a presumption that HP is false. For one thing, the critics seem to ignore the significant risk of skewed analysis generated by the so-called "selection effect." In addition to that, even if we focus on the limited sample of cases used by the critics, there is reason to doubt the claim that judges unambiguously speak as if they were setting out to discover what the law is in circumstances of disagreement about proper interpretive methodology. My second aim is to show why the defenders of HP have reason to insist that judicial interpretive practice in modern legal systems is rule-governed and that the rules in question are a matter of official consensus. So, I will not only make a negative case against the critics' objection but also a positive case in favor of HP.

\section{Problems With (P2)}

\section{How Pervasive and Mysterious is The Error?}

As I stated in the introduction, I will not be questioning the truth of (P1). But I need to say a few words about the presumption that is raised against error theories and about 
the conditions that need to be satisfied if that presumption is to be defeated. The idea is that error theorists must explain the origin and persistence of the discourse which they believe to be flawed: for why would people engage in and perpetuate a way of speaking and arguing that is based on assumptions whose falsity can be perceived by intelligent individuals? Again, there is no question that error theorists must be able to carry this burden if their view is to prevail. But it should be noted that the weight of the burden is not identical for all kinds of error theories. In metaethics, error theorists recognize that they have a specially heavy burden to carry because the error they assign is pervasive. The assumption that there are such things as mind-independent yet action-guiding moral properties/facts is arguably central to ordinary moral discourse. If that assumption is false, and error theorists argue that it is, then moral discourse is fraught with error.

It is a hazardous thing, however, to compare HP to error theories in metaethics. The error that HP assigns, I will argue, is limited to a select class of legal decisions and the explanation as to why flawed discourse persists within that class is readily available to the proponent of HP. While error theorists about moral discourse are concerned about explaining why most everybody is getting it wrong, proponents of HP are concerned about explaining why some judges are getting it wrong in some very special cases. (I will later suggest a further disanalogy between HP and error theories about moral discourse. While it is quite plausible to claim that ordinary moral discourse rests on realist assumptions, it is much less plausible to claim that judicial discourse within that select class of cases rests on the assumption that law is determinate. I put that to the side for now and concentrate on what makes the relevant class of cases special).

The critics tend to look for evidence of disagreement about proper interpretive methodology in the decisions of appellate courts. Decisions of the US Supreme Court are 
among the critics' favorites. It is surprising that the critics pay little attention to the perils involved in relying on decisions of high-level courts when attempting to substantiate general claims about the nature of judicial interpretive practice. There is no question that the decisions of a court like the US Supreme Court represent a small fraction of all the decisions published by American courts. More important than mere numbers, however, is the fact that this small fraction of cases is not selected randomly from the entire universe of legal disputes. Political scientists and philosophers have argued persuasively that the easiness (technical and political) of a case serves as a disincentive to litigation and appeal. ${ }^{3}$ Cases that reach high appellate courts are very likely to be technically complicated and highly politically charged (these features are not unrelated; I will argue later that the political complexity of a case may have an impact on its prima facie technical simplicity).

The first way in which HP differs from moral error theories, then, has to do with its frugal assignment of error to judges deciding a relatively small class of cases which are special in that they are legally and politically hard. The second difference between HP and moral error theories is closely related to the first. For the nature of the cases in which there is error is such that a plausible explanation of the origin and persistence of error immediately suggests itself. Judges in high appellate courts tend to deal with cases that attract public attention. The technical complexity of hard cases is specially attractive to legal scholars; their political complexity is attractive to the media and hence to the

3 For a couple of important empirical studies, the first one being specially influential, see G. L. Priest \& W. Klein, "The Selection of Disputes for Litigation" in Journal of Legal Studies 13 (1984) and L. Lederman, "Which Cases Go to Trial?: An Empirical Study of Predictors of Failure to Settle", in Case Western Reserve Law Review 49 (1999). For philosophical papers containing helpful discussions of the so-called selection effect, see F. Schauer, "Easy Cases" in Southern California Law Review 58 (1985); F. Schauer, "Judging in a Corner of the Law", in Southern California Law Review 61 (1988); L. Solum, "On the Indeterminacy Crisis: Critiquing Critical Dogma", in University of Chicago Law Review 54 (1988); B. Leiter, "Explaining Theoretical Disagreement" in The University of Chicago Law Review 76 (2009). 
general public. High appellate judges decide under the limelight, as it were, and behind that limelight there is a public which associates policy-making with the legislature and is reluctant to accept the democratic legitimacy of judicial activism. If judges are coy about disclosing the creative nature of their decisions in contexts of disagreement about interpretive methodology, the obvious reason for this is that they are understandably seeking to avoid the flak which overt activism tends to elicit - their lack of sincerity is specially understandable because judges are normally not given a choice; they must decide cases regarding which the law is silent, and they must at the same time fulfill their stereotypical role of law-appliers.

\section{Is there Error at All?}

Now, what I have said so far assumes that the critics are right to claim that, at least within the limited class of cases on which they focus, judges argue as if they were attempting to discern what the law is. This claim is crucial, for it is what commits HP to the view that judges are in error when they argue about the right solution to a legal problem in circumstances of disagreement about proper interpretive methodology. But the claim is dubious, if not utterly false. Judicial discourse at the high appellate level is quite elusive, and it is not at all clear that judges argue as if there were trying to discover what the law is. Judges often cumulate doctrinal with substantive (moral, political, economic) arguments in what has been derisively described as a "shotgun fashion:" the judge will "canvass all possible arguments in support of a position, repeat them for emphasis, and present them all without any regard for how they actually hang together as a coherent, principled position." ${ }^{4}$ To be sure, often judges will be a bit more careful about how

4 B. Leiter, supra note 3, at 1233. Leiter convincingly argues that such a strategy was employed by the majority in Riggs $v$. Palmer -22 NE 188 (NY 1889)- precisely one of the cases which has been taken to present difficulties for HP. 
they argue and will attempt to show that the substantive considerations to which they appeal are connected in important ways to the relevant formal rules: a substantive consideration may be presented as the rationale that underlies a formal rule or as the principle that unifies a body of formal rules.

None of this proves that judges in circumstances of disagreement about proper interpretive methodology do not argue as if they were trying to discern what the law is. The fact that judges rarely appeal exclusively to substantive considerations (as opposed to formal rules) suggests that judges indeed see themselves as being bound to some extent by rules which they have not created themselves. On the other hand, high appellate judges do frequently appeal to considerations of justice, utility, efficiency, etc. which cannot uncontroversially be characterized as parts of non-discretionary attempts to discern what the existing law requires. My point, once more, is that judicial discourse in hard cases is elusive. Formal and substantive arguments appear side by side and their connections are not always clear.

Note that, for a proponent of HP, this should not come as a surprise. If a judge's predicament involves juggling the obligation to decide a hard case and the obligation to fulfill the role of law-applier, one should expect the judge's discourse to reflect the tensions which afflict his reasoning. Judicial discourse is ambiguous because judges are subject to conflicting professional requirements.

\section{WHY BELIEVE THAT JUDICIAL INTERPRETATION IS RULE-GOVERNED?}

The foregoing considerations suggest the following picture. If HP assigns any error it assigns it to those judges who unambiguously argue in terms of law discovery and application (and not very many judges do that, I surmise) in circumstances of disagreement about proper interpretive 
methodology. This kind of disagreement does not appear to be widespread; it tends to occur in hard cases which tend to attract more public attention than the average case. Any simple comparison between HP and error theories in metaethics (theories which assign systematic error whose explanation is not nearly as straightforward) ${ }^{5}$ is rendered very suspicious. Is the limited and well explained error assigned by HP to judges capable of motivating a significant presumption against its soundness? Not to my mind.

In this section I will offer some general statements about judicial interpretive practice that will serve a twofold function. First, they will help to show that proponents of HP have good reason to believe that judicial interpretive practice is governed by (largely tacit) interpretive rules. Second, once these statements are made I will be able to reinforce the point of the previous sections by showing that some alleged examples of disagreement about proper interpretive methodology are not in fact instances of this kind of disagreement. The limited amount of examples on which the critics rely is probably even more limited than one may think. A brief examination of Riggs $v$ Palmer will help me to establish this point.

What evidence is there that judicial interpretive practice is rule-governed? A good part of that evidence comes from an influential collection of essays examining the interpretive practices of high-level courts in nine different jurisdictions. ${ }^{6}$ The essays point to the conclusion that judges abide by a broad rule (or perhaps standard, given its relative vagueness) that creates a strong presumption in favor of the plain meaning of formal rules. ${ }^{7}$ Where the plain mean-

5 Richard Joyce, for instance, a contemporary error theorist, argues that our erroneous belief in the categorical nature of moral reasons has to be explained by reference to our evolutionary history. The evolutionary story he tells is quite complicated and occupies a significant portion of his recent book, R. Joyce, The Evolution of Morality (Cambridge: MIT Press, 2006).

6 N. MacCormick and R. Summers (eds.), Interpreting Statutes: A Comparative Study (Aldershot: Dartmouth, 1991).

7 The authors focus on statutory rules. 
ing of a rule is not vague, ambiguous or otherwise indeterminate, judges will only deviate from it if they can provide strong arguments based on the supposed intentions of the authors of the rule or on pressing considerations of policy and principle that more often than not are presented as describing the underlying rationale of the very rule. The interpretive rule guiding this practice might be formulated thus: Plain meaning (when it is clear) is to be applied unless the results of so doing are very unsatisfactory (from a substantive point of view) or unless legislative intention is clearly at odds with plain meaning. This rule clearly has a penumbra of uncertainty (how unsatisfactory must the results be in order to qualify as "very" unsatisfactory?) but it also has a core of clear meaning and thus is capable of disposing of a large array of cases. ${ }^{8}$

I will now turn to a particular case, the famous Riggs $v$ Palmer, in order to provide more focused evidence for the claim that judicial interpretive practice is rule-governed in legal systems like that of the US. Riggs will also be the source of an important lesson about how to identify genuine instances of disagreement about interpretive methodology. In Riggs, the Court of Appeals of New York did not allow the defendant, Palmer, to inherit under the will of his grandfather, whom he had murdered. The court made this decision in spite of the fact that the plain meaning of the relevant statutes did not invalidate the grandfather's will. Plain statutory meaning, in this case, was arguably displaced by the substantive principle that "no man may profit from his own wrong." There are two interesting facts about Riggs. One is simply that plain meaning was discarded, a fact which may motivate suspicion about my claim that judges share a strong presumption in favor of plain meaning. The second fact is that there was a dissent in which

8 Note that the vagueness of this formulation of the rule is partly a function of the fact that it purports to encompass the subtly different practices that occur in all nine jurisdictions. The practices of each jurisdiction can be described somewhat more precisely. 
the idea of discarding plain meaning was contested: this fact motivates the idea that Riggs involved judicial disagreement about proper interpretive methodology. I argue in what follows that Riggs does not provide evidence against the presumption of plain meaning and also that Riggs did not involve disagreement about proper interpretive methodology. I will make these arguments in turn. Consider what Frederick Schauer has said about Riggs:

We can find numerous examples of courts allowing killers to take property that became available to them solely because of their own culpable actions, including cases involving a killer of the testator who was found not guilty by reason of insanity, a killer of the testator who was convicted of voluntary manslaughter, murderers whose acts of murder caused property to pass to their children although not directly to themselves, a murderer convicted of being an accessory after the fact but not of actually wielding the murder weapon, a murderer who did not kill a 'testator' but instead as remainderman killed the holder of the life estate... In all of these cases, all falling only slightly short of first and second degree murder, courts have allowed culpable killers to inherit, and have treated the Riggs $v$. Palmer principle, whether embodied in a statute or in the common law, as an exception to be construed narrowly, notwithstanding the broad potential implications of the 'no man may profit from his own wrong' principle. ${ }^{9}$

Again, focusing too narrowly on a case or small group thereof can lead to a skewed analysis. Once we take a step back and consider a sequence of cases that are quite similar to Riggs, an interesting pattern suggests itself. It is true that the judges in Riggs were willing to deviate from the plain meaning of the applicable statutes. But other judges in similar cases were not so willing. This lends credibility to the view that, instead of casually being ignored by the majority in Riggs, the statutes were found to make a prescrip-

9 F. Schauer, “The Limited Domain of Law", in Virginia Law Review 90 (2004), 1937-1938 (footnotes omitted). 
tion that was morally too objectionable to be enforced. Heirs often do rotten things and are allowed to get away with it, but murder, the judges believed, cannot be treated so leniently.

Let me consider now the dissent in Riggs. Judge Gray complained about the opinion of the majority in the following terms: “... the legislature has, by its enactments, prescribed exactly when and how wills may be made, altered and revoked, and, apparently, as it seems to me, when they have been fully complied with, has left no room for the exercise of an equitable jurisdiction by courts over such matters". ${ }^{10}$ It might appear, thus, that Gray is a committed textualist while the majority makes room for the exercise of "equitable jurisdiction" in certain cases. But this is dubious; Gray's supposed textualism is abandoned in a decision handed down on the very same day as Riggs. In Bockes $v$ Temple, Gray claims: "It is an elementary rule that statutes are to be interpreted according to their intent. The intention of the legislature is undoubtedly the great principle which controls the office of interpretation..."; and he qualifies that by saying that "[i]t is only where the literal acceptation of the words used will work a mischief, or some absurd result, or where some obscurity in the sense compels it, that we need resort to extrinsic aids of interpretation". ${ }^{11}$

So, did Gray have inconsistent views about legal interpretation? Not necessarily. Note that in Riggs Gray affirmed that "public policy" did not mandate a ruling against Palmer, since he was already being punished for his crime (22 NE 188 (NY 1889) at 519). It appears, then, that Gray did not see the result of applying the plain meaning of the statutes in Riggs as mischievous or absurd. Otherwise, he might have been willing to join the majority, for his decision in Bockes $v$ Temple identified mischief and absurdity as sufficient conditions for the use of "extrinsic aids of interpreta-

$1022 \mathrm{NE} 188$ (NY 1889) at 519.

11 Cited in Leiter, supra note 3, at 1433. 
tion" (which presumably includes intention and perhaps also moral considerations).

What does this analysis of Gray's decision teach us? First, it provides additional evidence in support of the view that judicial discourse can elude if analyzed superficially. One who reads Riggs and nothing else may come away with the mistaken impression that Gray was a hard core textualist. Second, and relatedly, it shows how the critics should not be too quick to classify judicial disagreements like the one in Riggs as instances of disagreement about proper interpretive methodology. It is just as plausible to say that the judges in Riggs were all abiding by the rule that gives precedence to plain meaning but allows for its defeat in exceptional circumstances. That is to say, the judges in Riggs were not employing different interpretive strategies but were disagreeing about how to apply a shared interpretive strategy in a particular case. How is this possible? Because the interpretive rule that governs judicial practice has a penumbra of uncertainty: it will not always be uncontroversial whether the conditions for the defeat of plain meaning have been satisfied.

\section{CONCLUSION}

Allow me to summarize my argument. First, consider its negative aspect. Error theories should indeed (I concede without argument) be presumed false. But this statement refers to theories that assign systematic error whose origin and persistence is not easily explained. HP is hardly an error theory in this sense. It assigns errors to those (few) judges who speak unambiguously in terms of law discovery in cases that are exceptionally complicated and attract an inordinate amount of attention.

As to the positive aspect of my argument, there is evidence, provided by analyses that are much more systematic than the critics', indicating that judicial interpretive behavior is rule-governed. The broad rule in question has a pen- 
umbra of uncertainty and it is likely that some of the putative examples of disagreement about interpretive methodology provided by the critics are in fact instances of disagreement that arise under the rule's penumbra. Recall Hart's famous example of a rule that did not permit vehicles in a public park. Disagreement might arise as to whether a bicycle is an instance of a vehicle and hence whether it should be permitted in the park. This kind of disagreement does not concern the critics, for it is not disagreement about proper interpretive methodology. All parties to the debate about bicycles may be convinced that the plain meaning of the rule should be enforced. The problem is that "vehicle" is a vague term and that bicycle is a borderline case. Similarly, in Riggs, the judges were probably not really disagreeing (although their rhetoric may suggest otherwise) about what interpretive method to apply. Instead, they disagreed about the application of a second-order interpretive rule with fuzzy edges. The question was simply whether Palmer's behavior was rotten enough to allow for the defeat of plain meaning. 